\title{
The Business Professional Doctorate as an Informing Channel: A Survey and Analysis
}

\author{
T. Grandon Gill \\ University of South Florida \\ Tampa, FL, USA
}

\author{
Uwe Hoppe \\ University of Osnabrueck \\ Osnabrueck, Germany
}

gill@coba.usf.edu uwe.hoppe@uos.de

\begin{abstract}
Although growing in popularity in other countries, the business professional doctorate has yet to gain traction in the U.S. Such programs, intended to offer advanced disciplinary and research training to individuals who later plan to apply that training to employment in industry, are frequently seen to be inferior to their academically-focused Ph.D. program counterparts. Furthermore, if the sole purpose of a doctorate is to develop individuals focused on producing scholarly research articles, that assessment may well be correct. We argue, however, that such a narrowly focused view of the purpose of doctoral programs is self-defeating; by exclusively focusing on scholarly research and writings, we virtually guarantee that our research will never make it into practice. The paper begins by identifying a variety of types of doctoral programs that exist globally and placing these in a conceptual framework. We then present a detailed case study of the information systems (IS) doctoral programs offered in Osnabrueck, Germany-where as many as $90 \%$ of candidates choose careers in industry in preference to academia. Finally, we proposesupported using both conceptual arguments drawn from the study of complex informing and observed examples - that the greatest benefit of business professional doctorates may be the creation of enduring informing channels between practice and industry. Presented in this light, the business professional doctorate should be viewed as an essential part of the broader research ecology, rather than as a weak substitute for the disciplinary Ph.D.
\end{abstract}

Keywords: doctorate, professional doctorate, DBA, complex informing, diffusion, action research, research ecology.

\section{Introduction}

A professional or practitioner doctorate can be described as a terminal degree that is either intended to qualify an individual for a particular profession or to enhance the skills of an individual. While common in some fields (e.g., medicine), these doctorates are relatively rare in businessparticularly in the U.S. The most obvious reason for the lack of interest in such programs is one

Material published as part of this publication, either on-line or in print, is copyrighted by the Informing Science Institute. Permission to make digital or paper copy of part or all of these works for personal or classroom use is granted without fee provided that the copies are not made or distributed for profit or commercial advantage AND that copies 1) bear this notice in full and 2) give the full citation on the first p.. It is permissible to abstract these works so long as credit is given. To copy in all other cases or to republish or to post on a server or to redistribute to lists requires specific permission and payment of a fee. Contact $0 \mathrm{HPublisher@InformingScience.org} \mathrm{to} \mathrm{request}$ redistribution permission. of design. Most business doctoral programs are specifically focused upon developing the skills required by an academic researcher. These skills, however, may not be directly applicable to practice. Thus, the professional interested in enhancing his or her skills through education will normally stop at the Master's degree level (e.g., MBA). In this paper, we specifically address the question of 
whether or not this conception of a business doctorate is necessarily beneficial to both industry and academia.

In this paper, our particular emphasis will be on the informing relationships that exist, or could exist, between academia and practice. To date, our failures in achieving such relationships have been severe (e.g., Gill \& Bhattacherjee, 2007; Pfeffer, 2007), a problem exacerbated by the substantial differences in knowledge structures employed by the two groups (Gill, 2008d). The argument we present is that professional doctorates, in business, can serve as a useful role in developing enduring informing relationships. Indeed, we believe that this role should be the primary motivation for establishing such programs.

We begin by looking at professional doctorates as they are conceived in different professions. We then specifically consider professional doctorates in business, an area where the situation internationally is far different from that in the United States (U.S.). To clarify these differences, we present a detailed case study of IS doctoral programs offered by the University of Osnabrueck in Germany, a country where senior executives with doctorates is the rule, rather than the exception (see Minzberg, 2004). In this program, we see vastly stronger linkages between doctoral students and industry in a learning environment that is far less structured than that of U.S. programs.

Using findings from the study of complex informing (Gill \& Cohen, 2008) and from the examples presented, we make a case that professional doctorates in business could play a major role in the communication of knowledge between academia and practice. Indeed, we go so far as to argue that without such programs, the long term role played by research in many business disciplines could decline to the point of complete irrelevance to both business and to academic institutions. To be successful in their informing role, however, professional doctoral programs will need to be designed very differently from their academic counterparts. We conclude by exploring these differences and recommending steps for establishing such programs.

\section{Diversity in Professional Doctoral Programs}

When one spends a career in a particular discipline and a particular country, it is easy to lose sight of the fact that doctoral degrees come in many different forms. Depending upon the particular field and profession involved, the importance attached to the doctoral degree- both for professional and academic purposes - can vary considerably. Some examples are presented in Table 1.

Table 1: Examples of Academic and Professional Doctorates

\begin{tabular}{|c|c|c|c|c|}
\hline Field & $\begin{array}{l}\text { Academic } \\
\text { Qualification }\end{array}$ & $\begin{array}{l}\text { Professional } \\
\text { Doctorate }\end{array}$ & $\begin{array}{l}\text { Required for } \\
\text { Practice }\end{array}$ & Comments \\
\hline Medicine & MD or Ph.D. & MD & Yes & \\
\hline Law & $\begin{array}{l}\text { JD, LLB, or } \\
\text { LLM }\end{array}$ & $\begin{array}{l}\text { JD, LLB, or } \\
\text { LLM }\end{array}$ & Yes & $\begin{array}{l}\text { Doctor of Law (JD), Bachelor of } \\
\text { Law (LLB) and Master of Law } \\
\text { (LLM) are very similar. }\end{array}$ \\
\hline Psychology & Ph.D. & Ph.D. & No & $\begin{array}{l}\text { Psychiatrists can prescribe medica- } \\
\text { tions and must have an MD in order } \\
\text { to practice. }\end{array}$ \\
\hline Engineering & Ph.D. & Ph.D. & No & \\
\hline Education & Ph.D. & Ed.D. & No & $\begin{array}{l}\text { An alternative professional terminal } \\
\text { degree, Ed.S. (Educational Special- } \\
\text { ist), is also offered. }\end{array}$ \\
\hline Business & Ph.D. & $\overline{\text { DBA }}$ & No & $\begin{array}{l}\text { Nomenclature for professional doc- } \\
\text { torate varies widely and a DBA can } \\
\text { mean very different things depend- } \\
\text { ing upon the granting institution. }\end{array}$ \\
\hline
\end{tabular}


Even in academia, a doctoral degree may not be required for faculty member status at premier research institutions. In the performing arts, for example, the Master of Fine Arts (MFA) would generally be considered a terminal degree; doctoral degrees in the area are rare. By the same token, receptivity to professional doctorates can vary considerably by situation. In many high level U.S. government posts, for example, a Ph.D. in Economics or Government might be a virtual prerequisite. The same degree might be of minimal, or even negative, value when applying for a position as an operating manager.

Where a doctoral or other terminal degree (e.g., LLB, LLM) degree is required for entry into a profession, an additional layer of requirements - such as board certification or the bar exammay be required. This type of certification may also be required for entry into other professions, such as accounting (the CPA exam) or public school teaching (state certification). Some researchers (e.g., Khurana \& Noria, 2008) have argued that in order to be considered a true profession, an occupation must combine educational requirements, certification requirements, and a mutually shared code of conduct (e.g., the Hippocratic Oath taken by doctors). For the purpose of the present paper, however, we will view a doctorate as "professional" whenever it serves as a qualifying or useful degree for the purposes on non-academic employment.

\section{Doctoral Program Designs}

A wide range of alternative doctoral degree patterns exists. Internationally, five of these patterns are commonly encountered (Huisman \& Naidoo, 2006) with a sixth - the online doctorateexpanding rapidly. These patterns are summarized in Table 2.

Table 2: Common Doctoral Program Designs (adapted from Huisman \& Naido, 2006)

\begin{tabular}{|c|c|}
\hline Name & Description \\
\hline Traditional Ph.D. & $\begin{array}{l}\text { Under the UK model, this doctorate principally revolves around a student } \\
\text { creating a dissertation under the supervision of one or two faculty mem- } \\
\text { bers. Little or no coursework is involved. }\end{array}$ \\
\hline Ph.D. by Publication & $\begin{array}{l}\text { Candidate is awarded the degree based upon a collection of completed } \\
\text { publications. The process by which the publications are created is not nec- } \\
\text { essarily controlled or supervised. }\end{array}$ \\
\hline Taught Doctorate & $\begin{array}{l}\text { This is closest to the standard U.S. Ph.D. model and involves a consider- } \\
\text { able amount of coursework in addition to a dissertation. The New Route } \\
\text { Ph.D. in the UK also follows this model. }\end{array}$ \\
\hline $\begin{array}{l}\text { Work-based or Practice- } \\
\text { Based Doctorate }\end{array}$ & $\begin{array}{l}\text { Particularly common in the performing arts, the degree is based principally } \\
\text { upon work-related activities or accomplishments. Clinical doctorates, such } \\
\text { as the MD, also have component elements resembling this pattern. }\end{array}$ \\
\hline Professional Doctorate & $\begin{array}{l}\text { A doctorate that focuses on applying program content to the candidates } \\
\text { work situation. }\end{array}$ \\
\hline Online Doctorate & $\begin{array}{l}\text { A doctoral program design based around online learning and independent } \\
\text { activity on the part of the student, with little or no residency requirement. } \\
\text { While providers of these doctorates-e.g., University of Phoenix, Cappella } \\
\text { University, Argosy University-are generally accredited as distance learn- } \\
\text { ing providers, they frequently lack disciplinary accreditation, making these } \\
\text { programs unsuitable for most faculty positions at research universities. }\end{array}$ \\
\hline
\end{tabular}

Of these doctoral degree patterns, the professional doctorate offers the greatest variation in activities. Nonetheless, the degrees present a fairly consistent pattern across many fields. In a survey of professional doctorates in the UK, Bourner, Bowder, and Laing (2001) identified 19 distinct ways in which they tend to differ from disciplinary research doctorates, summarized in Table 3. 
Table 3: Professional vs. research doctorates (adapted from Bourner et al., 2001)

\begin{tabular}{|c|c|c|}
\hline Attribute & Academic Ph.D. & Professional Doctorate \\
\hline 1. Career focus & Entry into academia & $\begin{array}{l}\text { Professional doctorates nearly always claim to } \\
\text { address the career needs of aspiring profession- } \\
\text { als }\end{array}$ \\
\hline $\begin{array}{l}\text { 2. Domain of re- } \\
\text { search topic }\end{array}$ & Disciplinary theory & Professional practice \\
\hline 3. Research type & $\begin{array}{l}\text { 'original investigation under- } \\
\text { taken to gain new knowledge } \\
\text { and understanding but not } \\
\text { necessarily directed towards } \\
\text { any practical aim or applica- } \\
\text { tion' (p. } 71 \text { ) }\end{array}$ & Issues of real interest to the profession \\
\hline 4. $\quad$ Research focus & $\begin{array}{l}\text { A perceived gap in the litera- } \\
\text { ture }\end{array}$ & A problem encountered in practice \\
\hline 5. Starting point & $\begin{array}{l}\text { Finding what is known in the } \\
\text { literature }\end{array}$ & A problem for which the solution is unknown \\
\hline $\begin{array}{l}\text { 6. Intended learn- } \\
\text { ing outcomes }\end{array}$ & Contribution to the literature & $\begin{array}{l}\text { 'A significant original contribution to knowl- } \\
\text { edge of } \\
\text { - professional practice through research, plus } \\
\text { one or more of the following: } \\
\text { - personal development (often specifying } \\
\text { reflective practice); } \\
\text { - professional level knowledge of the broad } \\
\text { field of study; } \\
\text { understanding of professionalism in the } \\
\text { field; } \\
\text { appreciation of the contribution of research } \\
\text { to the work of senior professional practi- } \\
\text { tioners.' (p. } 72)\end{array}$ \\
\hline $\begin{array}{l}\text { 7. Entry qualifica- } \\
\text { tion \& degree }\end{array}$ & $\begin{array}{l}\text { Undergraduate degree with } \\
\text { high marks }\end{array}$ & A Master's degree is often required \\
\hline $\begin{array}{l}\text { 8. Experience as } \\
\text { admissions re- } \\
\text { quirement }\end{array}$ & None & $1-5$ years usually expected, with a median of 3 \\
\hline $\begin{array}{l}\text { 9. Taught compo- } \\
\text { nent }\end{array}$ & $\begin{array}{l}\text { Minimal, under the "tradi- } \\
\text { tional Ph.D. model" }\end{array}$ & Ranges from 15 to $50 \%$ of degree requirement \\
\hline 10. Modularity & $\begin{array}{l}\text { Relatively unstructured ac- } \\
\text { cording to the "traditional } \\
\text { Ph.D." model }\end{array}$ & Modular course and credit structure \\
\hline $\begin{array}{l}\text { 11. In-service vs. } \\
\text { Pre-service }\end{array}$ & Pre-service for research career & $\begin{array}{l}\text { In-service for professional career, often taken } \\
\text { while working }\end{array}$ \\
\hline 12. Mode of study & Full-time & Part-time \\
\hline $\begin{array}{l}\text { 13. Integration of } \\
\text { work/study }\end{array}$ & N/A & High \\
\hline $\begin{array}{l}\text { 14. Integration of } \\
\text { practice/theory }\end{array}$ & Low & High \\
\hline 15. Cohorts & No & Yes \\
\hline $\begin{array}{l}\text { 16. Variability of } \\
\text { duration }\end{array}$ & Very high & Low \\
\hline $\begin{array}{l}\text { 17. Research out- } \\
\text { comes }\end{array}$ & Long dissertation & $\begin{array}{l}\text { Shorter dissertation, often more than one; pro- } \\
\text { ject reports }\end{array}$ \\
\hline 18. Assessment & Dissertation driven & Separately assessed components \\
\hline 19. Breadth & Narrowly focused & More broadly focused, problem-driven \\
\hline
\end{tabular}


Interestingly, the U.S. research Ph.D. model actually falls between the extremes of the UK "traditional Ph.D." and the professional doctorate. It shares most of its entry requirements and research philosophy with the UK model. With the professional model, however, it shares many organizational features: the taught component (9), modularity (11), cohort-based organization (15) and separate assessments (18).

\section{Motivation for Professional Doctorates}

Relatively little research has been conducted regarding the motivation for professional doctorates in those fields for which they are not a qualifying requirement. One study of 89 doctorates, not just professional doctorates, found that motivations of personal development and general intellectual interest outweighed vocational concerns (Leonard, Becker, \& Coate, 2005). Among the general patterns reported:

- Professional development and vocational requirements were mentioned by over a third of respondents. The authors attributed this to the increasing requirement for Ph.D. qualification in UK academics.

- Acquisition of research skills was mentioned by about one seventh of all respondents.

- Interest in the research area was mentioned by a third of the respondents.

- Personal development was mentioned by a quarter of the respondents.

- General intellectual interest and the joy of study were mentioned by a fifth of the respondents.

- Acquiring the named degree was mentioned by a tenth of the respondents.

What is particularly significant about these findings is the extent to which intrinsic motivation contributes to the desire to pursue a degree. This factor could be particularly important in launching new degree programs, as extrinsic motivators for a degree-based upon observable impact on the individual's career prospects - are unlikely to emerge for a new program until after a suitable pool of candidates has already acquired the degree and demonstrated its professional potential.

With these motivations in mind, it is possible to identify five motivational profiles that could, individually or in combination, lead an individual to pursue a doctorate, particularly a professional doctorate. These are summarized in Table 4.

Table 4: Motivational profiles for doctoral degrees

\begin{tabular}{|l|l|l|l|}
\hline Name & $\begin{array}{l}\text { Career } \\
\text { Stage }\end{array}$ & Objective & Comments \\
\hline D0.Traditional & Early & $\begin{array}{l}\text { Entry to aca- } \\
\text { demia }\end{array}$ & Traditional academic doctorate \\
\hline $\begin{array}{l}\text { D1. Advanced } \\
\text { Entry }\end{array}$ & Early & $\begin{array}{l}\text { Professional } \\
\text { development }\end{array}$ & $\begin{array}{l}\text { Doctorate is intended to advance the individual's profes- } \\
\text { sional career prospects. Particularly common in countries } \\
\text { like Germany, where doctorate is viewed favorably in } \\
\text { many professional contexts }\end{array}$ \\
\hline $\begin{array}{l}\text { D2. Continuing } \\
\text { development }\end{array}$ & $\begin{array}{l}\text { Mid- } \\
\text { career }\end{array}$ & $\begin{array}{l}\text { Professional } \\
\text { advancement }\end{array}$ & $\begin{array}{l}\text { Degree serves to enhance the individual's skills and repu- } \\
\text { tation }\end{array}$ \\
\hline $\begin{array}{l}\text { D3.Transition } \\
\text { Late- } \\
\text { Career }\end{array}$ & $\begin{array}{l}\text { Entry to new } \\
\text { career }\end{array}$ & $\begin{array}{l}\text { Doctorate serves as a try path to a new career, most com- } \\
\text { monly academia. The nature of the degree would depend } \\
\text { upon whether the principal motivation was change of } \\
\text { field, desire to research, desire to teach or desire to admin- } \\
\text { ister (e.g., join institution as a practice qualified dean). }\end{array}$ \\
\hline $\begin{array}{l}\text { D4. Personal } \\
\text { fulfillment }\end{array}$ & Any & $\begin{array}{l}\text { Self- } \\
\text { enrichment }\end{array}$ & $\begin{array}{l}\text { Little or no extrinsic motivation; motivation to pursue } \\
\text { doctorate is entirely intrinsic }\end{array}$ \\
\hline
\end{tabular}




\section{Business Professional Doctorates}

The most widely offered business professional doctorate degree appears to the Doctor of Business Administration (DBA). It would be a mistake, however, to equate the DBA degree with professional doctorates. To begin with, many professional doctoral programs, particularly in the U.S., offer alternative degrees, such as the Executive Doctor of Management offered by Case Western University. In addition, there are some DBA programs - such as that offered by Harvard Business School - where the purpose and organization of the degree is more closely aligned with that of a traditional academic Ph.D. For this reason, we will generally use the broader term business professional doctorates to include all degrees.

The proliferation and acceptance of professional doctoral programs in business varies considerably by region. Although the literature on the subject is not extensive, enough has been written on these programs to suggest the most activity is taking place in three distinct regions:

- U.S.

- UK and Commonwealth Nations (particularly Australia \& New Zealand)

- Continental Europe (particularly Germany)

While scattered programs may exist in other areas (e.g., Asia, South \& Central America, Africa), they have yet to achieve visibility. Thus, we content ourselves with considering the three regions.

\section{Programs in the U.S.}

Within the U.S., the number of DBA and equivalent professional doctoral programs remains quite limited. These programs generally seem to fall into three categories:

- AACSB accredited professional doctoral programs

- DBA and other doctoral programs that are not accredited by AACSB offered by nonprofit institutions

- DBA programs offered by for-profit distance learning-focused institutions

Particularly in the U.S., accreditation by the Association for the Advancement of Collegiate Schools of Business (AACSB) plays an important role in determining how a doctorate can be applied. Virtually all of top-ranked traditional business schools in the U.S. have that accreditation. Moreover, AACSB members are reluctant to hire faculty members with doctorates from nonAACSB accredited U.S. universities. Thus, the absence of AACSB accreditation drastically limits the transition to academic (D3 in Table 4) potential of the degree. In particular, barring stellar practitioner credentials, it would be nearly impossible for a doctoral student from a non-AACSB accredited institution to gain employment as a research faculty member at an AACSB university.

\section{AACSB accredited programs}

The number of AACSB-accredited professional doctoral programs in the U.S. is extremely limited. A recent study (Caldwell, White, \& Owl, 2007) reports four DBA programs in the U.S., offered by Harvard, Boston University, Louisiana Tech and Cleveland State University (CSU). Of these programs, the Harvard and Boston University programs are nearly indistinguishable from normal Ph.D. programs in their design and objective of qualifying candidates for careers in academia, although the average industry experience level of these candidates - based upon one of the author's personal observations - may be somewhat higher. It also appears that the Louisiana Tech program is moving in the same direction (Caldwell et al., 2007, p. 180).

The CSU program is somewhat different in its design and intent. It is described as follows: 
Cleveland State University's DBA program was also a politically created compromise, according to Associate Dean Raj Javalgi. Politically, the program was created because Cleveland State University (CSU) was unable to get a Ph.D. program approved with Kent State and Ohio State located proximate to CSU. The CSU DBA is a "niche program" that meets the needs of the working professional. Despite the fact that the CSU program is not a "daytime Ph.D." program, it has filled a high demand for students seeking opportunities to move from business to academia in Cleveland while being able to maintain a full-time job. Associate Dean Javalgi noted that the CSU DBA program has improved the reputation of the school's MBA program and has been a source of pride for the university. (Caldwell et al., 2007, p. 181, referencing a telephone interview conducted with Associate Dean Javalgi)

In our terminology, then, the program can be viewed as meeting the transition to academia (D3 in Table 4) objective.

We were able to identify only two additional professional doctorates in business at AACSBaccredited institutions: the Executive Doctor of Management (EDM) is offered by Case Western University (CWU) and the Doctor of Professional Studies (DPS) offered by Pace University. The EDM and DPS programs, in contrast to the DBA programs just mentioned, are not intended to serve as a means of transition to academia.

The CWU EDM, with its requirement for 10 years of work experience, it is clearly focused on continuing development (D2 in Table 4). Nonetheless, a number of its alumni do make their way into academia - a fact easily verified by searching Google on the degree and examining the resulting biographies - and a few of its students are drawn from academia where they use the degree as a means of acquiring terminal qualification, representing the transition to academia (D3 in Table 4) motivation. Also unlike the other accredited programs, the CWU EDM has relatively modest residential requirements, with classes offered at one 4-day and five 2-day residencies each semester over the course of three years.

The Pace University DPS degree is actually one of a number of DPS degrees offered by the university in different areas. It differs from the EDM degree in that it meets weekly-making it less suitable for out-of-area students - and appears to have a considerably more flexible admissions requirement. Far fewer DPS graduates could be found in searches of faculty member web sites, suggesting it would not normally be acquired in order to transition to academia.

It is not clear whether the population of AACSB accredited professional doctorates is growing or declining in the U.S. On the one hand, universities that once offered the DBA degree (e.g., Indiana University, Arizona State, and University of Southern California) have changed to a Ph.D. designation (Caldwell et al., 2007, p. 181). It is not clear, however, that these programs were ever really professional doctorates. On the other hand, at least two AACSB-accredited schools, both in Georgia, are introducing such programs: the Coles School of Business at Kennesaw State University (KSU) and the Robinson College of Business at Georgia State University (GSU) (Georgia State University, 2008). The professional program at KSU is described as follows:

Coles DBA is a unique, highly innovative, globally recognized doctoral degree in business - targeted to executives with a masters degree and extensive business experience. In a minimum 3-year part-time program, Coles DBA graduates will enhance their career flexibility and choice by preparing for expanded roles with their current employer or another organization, a consulting career, or to teach at the university level. We are confident the Coles DBA, led by a dedicated doctoral faculty with world class academic and corporate credentials will help you move to the next level in achieving your career. (Kennesaw State University, 2008) 
Scheduled to begin in fall 2009, it clearly targets both transition to academia and continuing development motivations (D2 and D3 from Table 4).

The program at GSU, on the other hand, appears to be strictly focused on continuing development motivation, since no mention of the possibility of transitioning to academia is mentioned anywhere on the program's web site. A press release describing the program includes the following:

Robinson's Executive Doctorate is one of only a few such programs in the world. Unlike other doctoral programs, the Executive Doctorate is targeted at senior executives who already hold an MBA or other advanced degree, are working full-time, and want to bring the knowledge they gain to bear on problems and issues within their organization. The program is designed to enable executives to understand the research process and to apply research in solving actual business problems.

In addition, Nova Southeastern University (see Table 5) is currently in the later stages of the AACSB accreditation process and will, therefore, likely join this group in the near future.

\section{U.S. non-AACSB accredited programs}

The number of non-AACSB accredited business programs in the U.S. also appears to be relatively small. According to the AACSB web site, there are six schools in the U.S. (excluding Puerto Rico) that offer business doctorates that are not AACSB accredited. Our own research also located a seventh (University of Maryland University College). These programs are summarized in Table 5. Once again, we emphasize that we are not making a judgment on the quality of nonAACSB degrees or institutions. Rather, we dwell on the issue of accreditation specifically because it relates to the prospects of subsequent doctoral student employability as research faculty members at institutions with a large research mission.

In addition to these programs, it is likely that a number of other U.S. business-related professional doctoral programs exist that are invisible to AACSB because they are housed outside of business schools, particularly in schools that separate IT management from business. A good example of such a program is the Doctorate of Science in Information Systems offered by the School of Communications and Information Systems at Robert Morris University, in Pennsylvania (Kohun \& Ali, 2005). That successful 3-year cohort-based program with limited residency requirements includes a significant managerial component and typically graduates 15 students per year. According to Dr. Kohun, the Associate Dean in charge of the program, roughly $60 \%$ of the students remain in industry, taking the degree for purposes of professional development, while $40 \%$ use the degree to transition to academia or, for individuals already employed as faculty members, to add doctoral credentials to their existing degrees.

\section{U.S. distance learning programs}

It is likely that some of the biggest producers of professional business doctorates in the U.S. are the large, for-profit institutions that specialize in providing distance learning opportunities for working professionals. These institutions currently include the University of Phoenix, Walden University, Argossy University, Capella University, Fielding Graduate University, and Northcentral University. These institutions are generally accredited, but mainly by distance learning agencies and by bodies whose membership does not normally include traditional universities. While the precise number of graduates produced by these universities is not readily available, these institutions contribute to a pool of distance learning and hybrid doctoral programs that is becoming reasonably large. 
Table 5: Non-AACSB accredited professional doctorates in business (from program websites)

\begin{tabular}{|c|c|c|}
\hline School & Degree & Description \\
\hline $\begin{array}{l}\text { George Fox } \\
\text { University }\end{array}$ & $\begin{array}{l}\text { Doctor of } \\
\text { Management }\end{array}$ & $\begin{array}{l}\text { GFU is a private Christian-focused university. Its DM program has lim- } \\
\text { ited residency ( } 4 \text { weeks/year) and consists of two tracks, one focused on } \\
\text { professional development and one focused on individuals interested in } \\
\text { pursuing teaching and training careers. No specific admissions require- } \\
\text { ments are specified. }\end{array}$ \\
\hline $\begin{array}{l}\text { Nova } \\
\text { Southeastern } \\
\text { University }\end{array}$ & DBA & $\begin{array}{l}\text { NSU is a large, private regional university that offers a wide range of } \\
\text { programs taught in both face-to-face and distance formats. Doctoral } \\
\text { classes meet one weekend per month for three months. Seven functional } \\
\text { tracks are available and the program specifically targets professional } \\
\text { development. Some graduates have successfully transitioned to research } \\
\text { positions in AACSB-accredited schools. Seven years of professional } \\
\text { experience, along with GMAT (550) and GPA (3.25) requirements, are } \\
\text { specified for admissions. }\end{array}$ \\
\hline $\begin{array}{l}\text { Southern New } \\
\text { Hampshire } \\
\text { University }\end{array}$ & $\begin{array}{l}\text { DBA in } \\
\text { International } \\
\text { Business }\end{array}$ & $\begin{array}{l}\text { SNHU is a medium-sized private university that is accredited in business } \\
\text { by an international agency (European Council for Business Education) } \\
\text { whose members are nearly all European. All classes are face-to-face and } \\
\text { meet once a week. Admissions requirements are an MS in International } \\
\text { Business (or equivalent) a minimum GMAT (560) and GPA (3.6). The } \\
\text { degree is reported to prepare students for careers in international busi- } \\
\text { ness, consulting and academia-particularly for positions outside of the } \\
\text { U.S. in the latter case. Some SNHU graduates appear to have taken U.S. } \\
\text { faculty member positions, particularly in non-AACSB accredited institu- } \\
\text { tions. }\end{array}$ \\
\hline $\begin{array}{l}\text { Stevens Institute } \\
\text { of Technology }\end{array}$ & $\begin{array}{l}\text { Ph.D. in } \\
\text { Technology } \\
\text { Management }\end{array}$ & $\begin{array}{l}\text { SIT is a private university, highly rated for its engineering programs. The } \\
\text { doctoral program is generally full-time and is relatively small (a recent } \\
\text { class consisted of } 5 \text { students). Admissions requirements are an MS in an } \\
\text { engineering specialty and } 85^{\text {th }} \text { percentile scores or better on the GMAT } \\
\text { or GRE. The program is particularly oriented towards research for pro- } \\
\text { fessional or academic career purposes. }\end{array}$ \\
\hline $\begin{array}{l}\text { University of } \\
\text { Maryland Uni- } \\
\text { versity College }\end{array}$ & $\begin{array}{l}\text { Doctor of } \\
\text { Management }\end{array}$ & $\begin{array}{l}\text { UMUC is a public university and one of the larger providers of distance } \\
\text { education in the country. Its Doctor of Management program is follows a } \\
\text { hybrid model, referred to as distance learning + residency. Students must } \\
\text { take the GMAT (waived if they have passed a specific prerequisite } \\
\text { course) or have a } 650 \text { or higher GMAT to skip the prerequisite. No GPA } \\
\text { requirements for admission is specified. }\end{array}$ \\
\hline Walsh College & $\begin{array}{l}\text { Doctor of } \\
\text { Management } \\
\text { in Executive } \\
\text { Leadership }\end{array}$ & $\begin{array}{l}\text { WC is a small, private university that offers face-to-face and distance } \\
\text { learning programs. It is accredited in business by an international agency } \\
\text { (International Assembly for Collegiate Business Education) that differen- } \\
\text { tiates itself from AACSB by virtue of its focus on teaching rather than } \\
\text { research. Requires } 5 \text { or more years of work experience, a minimum GPA } \\
\text { (3.3) and a GMAT score (minimum unspecified). The program is spe- } \\
\text { cifically directed towards professional development, although academic } \\
\text { administration is also mentioned. The degree was introduced in Fall } \\
2007 \text {, so no history of placements is available. }\end{array}$ \\
\hline $\begin{array}{l}\text { Webster } \\
\text { University }\end{array}$ & $\begin{array}{l}\text { Doctor of } \\
\text { Management }\end{array}$ & $\begin{array}{l}\text { WU is a large private university based in Saint Louis, MO but with a } \\
\text { large network of US (38) and international (5) site locations. It is accred- } \\
\text { ited in business by a U.S. based agency (Association of Collegiate Busi- } \\
\text { ness Schools and Programs) that was established to meet the needs on } \\
\text { non-research institutions. The D.MGT degree is offered only at the Uni- } \\
\text { versity's home campus. Admissions requirements are a Master's degree } \\
\text { and } 3 \text { years work experience; minimum GPA and test scores are not } \\
\text { specified. The program description specifically emphasizes professional } \\
\text { development but some academic placements can be found. }\end{array}$ \\
\hline
\end{tabular}


With respect to distance learning, in the 2006 Survey of U.S. Doctorates Summary Report (Hoffer, Hess, Welch, \& Williams, 2007), for example, two out of the top three positions, in terms of number of "other doctorates" category (which includes business), were held by non-AACSB accredited schools with substantial distance learning components (Nova Southeastern University, a not-for-profit hybrid program, was \#1; Walden University, a for-profit institution, was \#3).

The motivation for pursuing an online professional doctorate, particularly from a for-profit source, is unclear. Certainly, personal fulfillment (D4 in Table 4) represents a large part of it. Such a degree may also offer some opportunities for professional development (D2 in Table 4). There is, however, at least anecdotal evidence that businesses may be more receptive to the concept (EmploymentDigest.Net, 2006), particularly where acquiring the degree can complementrather than interfere with-the employee's work activities. We also found cases where faculty members appear to have supplemented their academic credentials with such degrees, although there is no easy way to gauge what benefits resulted from doing so. Nonetheless, such programs are generally quite expensive relative to public university costs and do not generally provide stipends. As a consequence, whatever the source of motivation, it must have been sufficient to compensate for considerable expense.

\section{Programs in the United Kingdom, Australia and New Zealand}

In the U.K. (and other non-U.S. English speaking countries), the DBA degree appears to be growing in popularity. In the U.K. 16 DBA programs had been identified by 1999 (Bareham, Bourner, \& Stevens, 2000). In 1999 alone, three programs were initiated (Bourner et al., 2001). Similarly, in Australia, 20 DBA programs were initiated between 1993 and 2005 (Fink, 2006). Because many of these institutions have traditionally been nearly entirely dependent upon state support, a potential motivation for such programs may be revenue generation from professional student fees.

Because of the large number of programs that have been initiated in these regions, most of the existing research on business professional doctorates is based upon programs from these regions. In addition to the already referenced research on program design (e.g., Table $2 \& 3$ ) and participant motivation, additional research topics include the institutional challenges presented by such programs, individual costs/benefits of such programs, potential motivations of businesses to participate in the programs, and project models typically incorporated in such programs. Some of the key findings and conclusions from this research are summarized in Table 6.

\section{Programs in the European Union}

In Europe the distinction between professional and academic business doctorates is very much blurred. Part of this reflects the fact that European doctoral programs are in a state of flux, brought about by the recent adoption of the Bologna Accords. Even more critical, however, the doctoral degree is already a widely accepted credential in business in some EU countries, particularly Germany (although variations in acceptance across EU borders remains high).

\section{The Bologna Process}

The Bologna Process aims to create a European Higher Education Area by the year 2010. The Bologna Declaration of 1999 (http://www.bologna-bergen2005.no/Docs/00-Main doc/990719 BOLOGNA DECLARATION.PDF) has initiated a reform process in order to make European higher education more compatible and comparable, more competitive, and more attractive for European and international students and scholars. The process involves three main goals: 1) introduction of the three cycle system (Bachelor, Master, \& Doctorate), 2) quality assurance and 3) mutual recognition of qualifications and periods of study. 
Table 6: Selected research findings from U.K. and Commonwealth nation DBA programs

\begin{tabular}{|c|c|}
\hline Name & Findin \\
\hline $\begin{array}{l}\text { Institutional } \\
\text { challenges }\end{array}$ & $\begin{array}{l}\text { - Doctorates appear to be migrating away from coursework plus thesis model to a less } \\
\text { familiar portfolio of skills and activities approach, referred to as "second generation" } \\
\text { professional doctorates (Maxwell, 2003) } \\
\text { - Substantial effort may be required to address resistance from academic culture; profes- } \\
\text { sional doctorates can easily revert to more academic models over time (Boud \& } \\
\text { Tennant, 2006) } \\
\text { - Skills required for supervising professional doctorates differ from those suitable for } \\
\text { academic counterparts; attitude changes and training may be necessary (Boud } \\
\text { \&Tennant, 2006). Faculty need skills in conduct of action research (Coghlan, 2007) } \\
\text { - Needs to move from knowledge producer and transmitter model to cyclic (spiral) in- } \\
\text { teractions with practice (Lester, 2004) } \\
\text { - With more DBA providers in the market, institutions will increasingly need to focus } \\
\text { programs (Lockart \& Stablein, 2002) } \\
\text { Need to address faculty member and student view that professional doctorate lacks the } \\
\text { international currency and status of the Ph.D. and is of lesser quality and standards; } \\
\text { concerns of "creeping credentialism" (Neumann, 2005) }\end{array}$ \\
\hline $\begin{array}{l}\text { Individual } \\
\text { costs \& } \\
\text { benefits }\end{array}$ & $\begin{array}{l}\text { - A large percentage of individuals were self-funded (40\%) or largely self-funded (about } \\
\text { a third) (Leonard et al., 2005) } \\
\text { - New jobs, promotions and increased security were mentioned as benefits by some } \\
\text { (Leonard et al., 2005) } \\
\text { - Doctorate serves as "a vehicle for self-managed development as a leading professional } \\
\text { taking forward an area of practice" (Lester, 2004) }\end{array}$ \\
\hline $\begin{array}{l}\text { Potential } \\
\text { business } \\
\text { motivations }\end{array}$ & $\begin{array}{l}\text { - Today's information economy offers greater return for managerial research skills } \\
\text { (Bareham et al. 2000) } \\
\text { Business interest in DBA is sparked by dissatisfaction with traditional Ph.D. (Bourner } \\
\text { et al., 2001; Park, 2005); professional doctorate may be better aligned with the knowl- } \\
\text { edge economy (Usher, 2002). } \\
\text { - DBAs can increasingly meet research needs of business (Lockart \& Stablein, 2002) }\end{array}$ \\
\hline $\begin{array}{l}\text { Project } \\
\text { models }\end{array}$ & $\begin{array}{l}\text { - Projects cut across disciplinary boundaries and are driven by the exigencies of work or } \\
\text { originated from it } \\
\text { The relationship between their professional experience and the doctoral engagement of } \\
\text { candidates varies and they will require different strategies for researching/analyzing } \\
\text { their practice needs of a particular academic or professional community } \\
\text { - Investigating practice is common theme of research } \\
\text { - University adds value through providing the skills, tools and conceptual apparatus to } \\
\text { analyze workplace/professional experiences: it is not, however, immediately obvious } \\
\text { how it does so when candidates are not located as part of the existing academic organ- } \\
\text { izational structure. } \\
\text { Motivations are complex and are not those of gaining a vocational qualification for a } \\
\text { research career. (list summarized from Boud \& Tennant, 2006, p. 300-301) } \\
\text { Project research tends to be outcome-driven rather than process-driven, collaborative } \\
\text { rather than individual (Fink, 2006) }\end{array}$ \\
\hline Other & $\begin{array}{l}\text { - DBA programs generally do not emphasize acquisition of knowledge of business sub- } \\
\text { ject matter (Bareham et al., 2000) } \\
\text { - There is no broad consensus regarding what a DBA is about; there is a need for such } \\
\text { consensus if the degree is to progress (Bareham et al., 2000) } \\
\text { - Prospective doctoral candidates are increasingly older, with greater } \\
\text { levels of professional experience that they wish to integrate with their doctoral studies } \\
\text { (Boud \& Tennant, 2006, p. 299) } \\
\text { - Professional doctorates, such as the DBA, can be quite profitable (Neumann, 2005) }\end{array}$ \\
\hline
\end{tabular}


As an integral part of the Bologna Process and first stated in the Berlin Communiqué of 2003 (http://www.bologna-bergen2005.no/Docs/00-Main_doc/030919Berlin_Communique.PDF), doctoral programs are considered as the third cycle. Goals and strategies for the third cycle areowing to their relatively late introduction to the Bologna Accords - still rather abstract and in need of further operationalization.

The progress of the Bologna process is documented in a series of biannual reports, the latest report being "Trends V." That report was based upon a quantitative survey of higher education institutions undertaken between November 2005 and March 2006 with 908 questionnaires included in the analysis for the report. The survey has been amended by a qualitative series of interviews at 15 higher education institutions in 10 countries, visited between October and December 2006. Interview partners have been rectors, vice-rectors, deans, academics, junior lecturers, early-stage researchers, students from all cycles, and administrative staff.

The authors of "Trends V" have described the speed at which doctoral programs have undergone change as a "mini-revolution" (Crosier, Purser, \& Smidt, 2007, p. 25). Meeting the dynamically changing requirements of labor markets in Europe is a clear goal in restructuring doctoral programs:

Employability of doctoral candidates within and outside academic institutions, as well as individual and societal needs for lifelong education and training, have acted as a catalyst to the development of new programmes, including professional doctorates, more university-industry collaboration based doctorates and increased European and international cooperation, often leading to joint or European doctorates. Programmes known as 'Professional Doctorates' or practice-related doctorates merit particular attention. (Crosier et al., 2007, p. 28)

The study points out that the experiences with the fast growing number of these programs, particular in the UK, should be disseminated to other countries.

As a result of the transitional process of Bologna only five smaller European countries still offer programs following the Traditional Ph.D. Design (as per Table 2) as their only options for students. 16 countries, including Germany, the Netherlands, and most parts of Scandinavia have additionally adopted programs following the Taught Doctorate pattern (Crosier et al., 2007, p. 2627).

To describe the actual status of doctoral programs in 27 different European countries or in the 45 countries participating in the Bologna reforms is beyond the scope of the present paper. Instead, we focus on some of the bigger European countries to illustrate the variations in appreciation of doctoral degrees by industry. Because the attractiveness of a doctoral degree for both student and potential employer strongly depends upon the content of the respective doctoral programs and their requirements in space and time, we also describe these characteristics.

\section{Germany}

In Germany two different paths to a Ph.D. degree can be distinguished. The MasterApprenticeship Model, following the Traditional Ph.D. Design (Table 2), is relatively unstructured in form. The selection processes of candidates are informal, usually depending upon a personal contact of the applicant with a professor, during which the prospective student tries to convince him or her about a dissertation theme. Being accepted, the programs do not require or offer courses. The final thesis gets graded, complemented by either a "Disputation" (an oral defense of the thesis in front of members of the faculty) or a "Rigorosum" (a broader oral exam about subjects of the field in which the doctoral degree is being pursued). The doctoral degree serves as a qualification for academic positions as well as for industry careers. Out of an estimated number of 70,000 to 80,000 doctoral students in Germany in $1999,50,000$ to 55,000 were enrolled in such 
programs (Janson, Schomburg, \& Teichler, 2006, p. 32). Thus, from a numerical standpoint, "Master-Apprenticeship" is the dominant model in Germany. The students are financed with working contracts from the chair of the program and their mentor. The contracts usually guarantee the students $1 / 3$ of their working hours for personal research, most notably their dissertation project. The rest of the time is filled with administrative and teaching duties. These contracts might be given on a fulltime or part-time basis. In the Business Sciences, contracts specifying between $75 \%$ and $100 \%$ of 40 working hours per week are most common since these positions compete with industry jobs for the best graduates and cannot attract good candidates if they are too poorly paid.

The traditional model has been subject of criticism (Wissenschaftsrat, 2002) stating that:

- the students are too dependent upon their mentor,

- a student's mobility is low (many doctoral students are recruited directly after finishing a Diploma or Master's degree at the same university),

- it lacks competitive selection processes and accompanying quality assurance,

- aspects of internationalization are scarce,

- the average period of obtaining the degree is too long,

- the mixing of administrative, teaching and research tasks is counterproductive for successfully finishing the program.

Starting in 1990, this critique has led to the introduction of Graduate Schools doctoral programs, translated from the German "Graduiertenkolleg" or "Graduiertenschule" (since Germany lacks a consistent term for this type of doctoral programs; Janson et al., 2006, p. 48). These employ the Taught Doctorate design (Table 2). In 2003 the German Research Foundation alone financed 283 of these programs, which combine course work with a dissertation over a period averaging 3 years, based on a stipend for the doctoral students. As opposed to U.S. programs, these graduate schools are installed for limited periods of time, after a competitive phase of proposal and evaluation, and need to undergo reevaluation in order to be further financed. They are typically centered on an innovative, interdisciplinary thematic focus. In 2004 approximately $10 \%$ of German doctoral students were enrolled in such a program (duz SPEZIAL, 2004, p. 13).

The Graduate School model in Germany has been critiqued as well. In some disciplines it has become difficult to get the needed number of high potential applicants. Interestingly, even those students who plan for an academic career sometimes prefer the traditional Master-Apprenticeship Model, because they expect a better preparation for the job in terms of teaching experiences, project management, administrative tasks, and other key qualifications of the profession (Wissenschaftsrat, 2002, p. 24).

With respect to questions regarding the nature of preparation provided by these programs, the recommendation of the German Scientific Counsel is unequivocal (Wissenschaftsrat, 2002, p. 46): doctoral programs can not solely focus on the requirements of academic positions but must prepare students for industry positions as well. To realize such conflicting goals, the Counsel admits that doctoral programs cannot be the only preparation for becoming a professor but, instead, should be amended with post doctoral programs like the German Junior Professorship (a postdoctorial qualification phase of up to six years, preparing for a professorship) or the still prevailing habilitation (Wissenschaftsrat, 2002, p. 49), which initiates a state-sponsored form of lifetime professorial tenure.

The clear majority of doctoral students in the Business Sciences in Germany do not intend to pursue an academic career. Instead, they use the degree as an Advanced Entry (D1 in Table 4) into industry or administration. This can be derived from statistical facts: in 2004, 2005, and 2006 the 
number of successful dissertations in the Business Sciences were 981, 1208, and 1303 respectively (Statistisches Bundesamt, 2008). During the same years, the numbers of habilitations (still the main path to becoming a professor in Germany) were 98, 85, and 76. Only five out of a hundred successful doctoral students in the Business Sciences in 1999 achieved a subsequent habilitation (Enders \& Bornmann 2001). Moreover, one year after the completion of the dissertation, only $19 \%$ of these students were still working at a university while $81 \%$ had moved to industry.

Doctoral students with a Continuing Development (D2 in Table 4) motivation are called "external doctoral students" because they usually do not quit their job during the program but stay with their employer, sometimes facilitated by part-time contracts or temporary releases ("Sabbaticals"). They are not a target group for the newly introduced Taught Doctorates because they cannot generally attend the integrated courses nor do they want to; they are aiming at higher career opportunities in business. As a consequence, they usually participate in programs following the Traditional Ph.D. design (Table 2) and will continue to do so regardless of the Bologna reforms as long as Germany does not implement explicit professional doctorate programs comparable to those in the UK.

One estimate places the number of senior German executives with doctorates at as high as $80 \%$ (Minzberg, 2004). Thus, there is no doubt that a doctoral degree in Germany is highly valued among employers in various industries (Baldauf, 1998; Enders \& Bornmann, 2001). Franck and Opitz (2007) have characterized the university systems in the U.S., Germany and France as filtering mechanisms, serving to signal potential employers regarding the quality of graduate job applicants. Examining the degrees of CEOs of the one hundred largest companies in the three countries under consideration, the researchers found that in the U.S. 5.6 percent of the CEOs held a doctoral degree and in France the number was an even smaller 4.1 percent. In Germany, on the other hand, no less than 58.5 percent held a doctoral degree. The researchers proposed that these findings could be explained by differences in the structure of the respective university systems. The high percentage in Germany results from the fact that German universities do not exhibit large variations in perceived quality. In such a situation, high potential students then enroll as doctoral students in order to stand out from other graduates through demonstrating that a professor - presumably, a discerning judge of the student's potential— has picked them.

\section{France}

France (Wissenschaftsrat, 2002, pp. 37-39) has seen reform processes similar to Germany's. In 1984, four different doctoral degrees were abandoned in favor of a uniform degree ("Doctorate Unique"). As in Germany, the U.S .model of Taught Doctorate (Table 2) serves as the ideal. The research oriented education of doctoral students typically starts with enrollment in a DEAprogram (Diplôme d'Études Approfondies) with course requirements and a final exam, followed by an admission to a doctoral school ("École doctorale") that usually lasts 3 years. Ph.D. programs in France have long been supposed to prepare candidates solely for academic careers - an impression that is still largely valid since Ph.D.s are considered as being isolated from the practical requirements of industry and administration.

In France, the "Grandes Écoles" serve the particular role of preparing highly qualified persons for top executive positions. These universities typically have a low profile in research and do not offer doctoral programs. In the previously mentioned study from Franck and Opitz (2004) about universities as filtering mechanism that signal highly qualified future leaders, $97,3 \%$ of the CEOs of the 100 top-capitalized French companies had a university degree, but only $4,1 \%$ of them obtained a doctoral degree. Furthermore, it could not be shown that French doctoral degree holders who pursue a career in the private or public sector received higher wages (Recotillet, 2007). Thus, the degree from a Grande École serves as sufficient signaling mechanism. No subsequent doctorial degree is necessary, or even desirable. 


\section{Netherlands}

In the Netherlands (Wissenschaftsrat, 2002, pp. 39-40) drastic reform efforts took place in the $1980 \mathrm{~s}$ and 1990s. As a result so called Onderzoekscholen were introduced, usually supported by several universities and hosting between 40 and 100 doctoral students. These schools are similar to German Graduate Schools in that they are institutionalized only for a limited time and have to undergo reevaluation for further financing. As opposed to Germany, their thematic focus usually follows the traditional boundaries of scientific disciplines. Selection of applicants is competitive, course work is mandatory. Due to the comparative size of the Netherlands, the approach can be viewed as a focusing strategy involving practically all doctoral students in the country. At any given time, up to 10 Onderzoekscholen get significant budgets and a very limited in time in which to establish centers of excellence.

\section{IS Doctoral Programs at the University of Osnabrueck}

To better understand the implications of doctoral acceptance by practice, we now turn to a case study describing the IS doctoral programs at the University of Osnabrueck. By considering this case, we can better understand how interactions between business and academia are transformed in such an environment.

\section{Program Description}

The University of Osnabrueck (UOS) is a medium-sized university with approximately 10,000 students. The UOS is organizationally structured in ten faculties including the Natural Sciences, Social Sciences, Law, Business Sciences, and other smaller areas. The smallest independent organizational unit is the chair. The chair of Organization and Information Systems - roughly corresponding to Management Information Systems (MIS) in U.S. terminology —is part of the faculty of Business Administration and Economics.

As a result of the Bologna process, study programs in German Business Sciences are being transformed into far more specialized Bachelor and Master programs. In Osnabrueck, new Bachelor and Master Programs have recently replaced a Diploma Degree which had been the only graduate degree offered from the foundation of the faculty from 1977 until October 2007. The UOS is taking advantage of this transitional process to focus on the fields of Accounting, Applied Economics, and Information Systems in order to distinguish itself from competing institutions. This strategy is supported by the fact that approximately $60 \%$ of the professors in the faculty were going into retirement between 2006 and 2009, giving the university the chance to hire new staff that serve the newly defined focuses in teaching and research.

The whole faculty shares a common doctoral program awarding a degree Dr. rer. pol. (rerum politic arum), which, for the purposes of comparison, can be equated with a Ph.D. in Business, Economics or MIS in the U.S. The program has minimal structure. Requirements for successful students are:

- A thesis proving the applicant's ability to independently do scientific research,

- An oral exam after acceptance of the thesis covering: a) a major subject with selected themes from Business Administration, Economics and MIS, and b) a minor subject that can be chosen from graduate courses offered by all faculties of the university.

The only course requirement is typically a graduate level seminar in a minor subject. The thesis is advised by a tenured professor from the faculty. A second professor is asked to grade the thesis in the year of completion (although students are encouraged to involve that individual much earlier in the process). This tight relationship between an advising professor and the candidate is typical of the previously described Master-Apprenticeship model. 
In the faculty, doctoral students need, on average, four to five years to finish their dissertation. Subsequently, they overwhelmingly choose to leave the academic system and to take a position in industry. These students often serve as important informing channels between academia and practice. Three out of four doctoral students work with a chair and, therefore, build a tight relationship to the chair holder, often lasting for the rest of their professional careers. Moreover, such relationships often begin prior to entry into the doctoral program. For example: one of the MIS students who finished his Master's degree in 2007 subsequently contacted one of his former MIS professors a couple of month later. It turned out that he had taken a job at one of the "Big Four" global accounting firms. In that position he had been made responsible for university contacts - a position created because corporations in Germany are starting to recognize the changes in German study programs and the need to identify those universities that deliver applicants best suited for their job and industry profiles. The former student informed the professor that, due to the newly established focus of the UOS in Accounting, the university had earned "highest interest" (category A in an internal classification scheme) from the company. As a consequence of this established contact, a new study course was developed that would be supported by the company's top managers, to commence in 2009. Accompanying this development, the company has become a receptive site for case studies and other research activities.

\section{External Doctoral Students}

External doctoral students, who already have a job in the industry and would like to improve their career prospects with a doctoral degree, are also common at the UOS. These students are "external" in the sense that they are not working on a contract with the chair (as internal doctoral students do). They approach a professor while working for a company and with the intent of keeping their job as they work on their dissertation project. External students leverage their work experience and often supply company projects/problems to be addressed in their dissertations. This kind of student is of particular interest as a prospective informing channel because he or she already has already reached a certain level in the hierarchy of the company and has insights into the problems that need to be solved. Of key importance, these students also generally intend to stay in their business. Thus, they can be invaluable in the transfer of information across academic/industry boundaries.

Between 2000 (start of the chair holder as professor in Osnabrueck) and 2008, three external doctoral students successfully completed their dissertation. At the time of writing, six more were "in the pipeline." Descriptions of three of these students are now presented:

Ronald Poppe contacted the chair while working as consultant for the global management consulting, technology services and outsourcing company Accenture. As a manager of Accenture's consulting service line "Supply Chain" he has specialized in supply chain management related projects with a special focus on process reengineering and IT-system integration.

Leveraging his 7-years experience gained through numerous projects in the automotive and pharmaceutical industry, his dissertation focused on real life challenges in supply chain collaboration. With his dissertation theme "Achieving Supply Chain Management Excellence through Collaboration Platforms" he examined the organizational as well as the technological integration of external supply chain partners.

Poppe was very successful at integrating practice and theory. On the one hand, he utilized his first hand observations of best practice examples for implementing a collaboration platform to manage the complexity of multi-tier supply chains. At the same time, he used academic methodologies, frameworks and reference models to structure the problem, to derive general design principles, and to elaborate a conceptual framework for collaboration platforms within the supply chain management arena. 
His contributions to bridging the academic/practice gap did not end with his research. He also advised bachelor and master students writing their theses by providing them with themes that could serve as building blocks in the bigger picture of his dissertation. These themes were always driven by concrete consulting projects or internal research projects for the consulting market.

Publications from Ronald include an article about supply chain coordination in the journal Supply Chain Management and a conference paper about collaboration platforms as a means to reduce barriers of diffusion in supply chain management.

Heike Gastl contacted the chair while working as a consultant for McKinsey. Her working field at that time was IT-Management, comprising subjects like IT-Organization, IT-Governance, ITOperations, IT-Infrastructure and Cost \& Activity Accounting for IT. Additionally, she has worked on studies investigating post merger integration in the financial industry. Her dissertation theme was "Reference Model for Companywide E-Learning in Knowledge-Intensive Large Scale Enterprises." The model evolved from two sets of interviews with top and middle managers responsible for e-Learning and Knowledge Management. Because her dissertation was thematically different from her work activities, the main benefits derived from her job have been:

- Experiences in project management to structure her dissertation project,

- Regular discussion meetings with other doctoral students at McKinsey in the Hamburg office,

- The extremely well developed network of contacts of the company, which she used to find interview partners for her dissertation.

During her time in the program, she wrote an article (together with Frederic Ahlemann, discussed later) on empirically grounded reference model construction and a working report about the relationship of e-learning and knowledge management.

Heike benefited from a sabbatical the corporation offered her to ease the completion of the dissertation.

Frederik Ahlemann had received an excellent Diploma (comparable to a Master of Science) in Information Systems and was working for an Arthur D. Little spin-off when he contacted the chair. The company advised corporate customers in the area of project management. Ahlemann found that few scientific studies were available describing typical processes and structures for the project controlling of large scale enterprises. He resigned from his position at the company to become a research assistant of the chair. During that period, however, he stayed in tight contact with his former employer. His publications and activities on his way to completing his dissertation included:

- Das M-Modell. Eine konzeptionelle Informationssystemarchitektur für die Planung, Kontrolle und Koordination von Projekten: a research report; the M-Model is a Life Cycle Model for the planning, controlling and coordinating of projects.

- Ahlemann, F.; Backhaus, K.: Project Management Software Systems - Requirements, Selection Processes and Products, 4th edition, BARC, Würzburg, 2006 (1st - 3rd edition: Comparative Market Analysis of Project Management Systems): A comparative study of main software systems in this area; sales have been generated revenues approx. $\$ 100,000$ for the chair.

- Ahlemann, F.: Referenzinformationsmodell für das unternehmensweite Projektcontrolling in Matrixprojektorganisationen, Fachbereich Wirtschaftswissenschaften/ Universität Osnabrück, 2006: His dissertation.

- The coordination of the development of a DIN-Standard for project management, based on his work in project controlling, in a working group of 10 small and midsized firms- 
again resulting in valuable contracts. (DIN is the German Institute for Standardization, a body whose mission is to develop norms and standards as a service to industry.)

Ahlemann's relationships to practice produced numerous benefits over the course of his program. These included:

- Contacts to interview partners needed for his dissertation,

- Considerable revenues for the chair,

- The study of project management software systems generated considerable interest from industry. Several projects resulted from these contacts, usually in the form of in-company workshops of several days duration in order to reengineer partial processes in project controlling (e.g. the initiation process) or to support the selection of an appropriate software tool for the corporation. These projects again generated revenues for the chair and gave Ahlemann more access to interview partners for his dissertation.

Ahlemann became an assistant professor at the European Business School in Oestrich-Winkel, Germany. The European Business School is one of the leading private universities in Germany with an explicit focus on industry contacts while maintaining a high profile in research. In this new role, he supervised a group of doctoral students, many of whom are co-financed from industry, splitting their working hours between university and industry and working on corporate problems. Thus, his motivation profile can be characterized as a mixture of "D3 - Transition" (although his working experiences in industry before starting the dissertation project had been rather short) and "D0 - Traditional," aimed at acquiring an academic position.

These three examples show how all sides - industry, student and /university/chair-benefit when the doctoral degree holder serves as an informing channel. The main challenge seemed to be defining a dissertation theme that fulfills two requirements: qualifying as a relevant corporate problem and as a scientifically valid piece of research.

\section{Future Challenges}

While the described professional doctorates continued writing their dissertation under the Traditional Ph.D. design (Table 2), the Bologna process introduced new challenges from the standpoint of doctoral programs. The faculty of Business Sciences at UOS pursues a strategy of improving research quality, mainly by focusing on publications in highly rated international journals. An indicator of this focus can be seen in the filling of faculty positions from 2006 through 2008. As previously noted, more than half of the sixteen faculty professors had to be replaced due to a wave of retirement - a situation being experienced by nearly all German faculties in various disciplines. The newly obtained colleagues were universally strong in publishing, with a quantified measurement of publications in the last five years playing an important role in the selection process. To support the quality strategy, preparation for an additional doctoral program began. It was intended to follow the Taught Doctorate design (Table 2), including course work, integrated evaluation, and institutionalized responsibilities for committees of faculty. This transition raised the question of how, in the future, external doctoral students could fit into the new design. The main problem was that, with the more structured program, incongruities between approaches become evident, as illustrated in the Table 7 estimates, which characterize the expected working conditions of various types of doctoral programs.

Although the numbers in Table 7 are estimates based on small samples, they provide some interesting insights. For example:

- The working conditions of doctoral students in the Traditional Ph.D. design needed to be improved to be competitive with those students working in a Taught Doctorate situation. 
- Stipend-based Taught Doctorate programs could reduce the average time to obtain the degree significantly.

- Professional doctorates had a large range in the workload required by their dissertation, depending on how well they could reconcile their company tasks with their dissertation theme.

Germany still maintains a second qualification phase for becoming professors (habilitation or Junior Professor position) due to the trade-off in requirements of doctoral students either heading for academia or for industry. In recognition of this phase, it would be reasonable to think about a separation in doctoral degrees (i.e. introducing a DBA or similar degree), supporting the different focus of the program, different emphasis in course work, and different requirements (e.g., the practice thesis could be shorter). This would be in accordance with the recommendations of the German Scientific Counsel. It would open the opportunity to reduce the second qualification phase (habilitation or Junior Professor). It might even serve to increase the already large number of professionals who are looking for a chance to obtain a doctoral degree.

Table 7: Working conditions of doctoral students at the UOS and estimated dissertation time.

\begin{tabular}{|c|c|c|c|c|}
\hline student & Time [years] & $\begin{array}{l}\text { Percentage for } \\
\text { dissertation } \\
{[\%]}\end{array}$ & Workload [hours] & Degree \\
\hline $\begin{array}{l}\text { Internal doctoral } \\
\text { student (Tradi- } \\
\text { tional Ph.D.) }\end{array}$ & $4-5^{*}$ & $30 * * *$ & $2160-2700$ & Dr. rer. pol. \\
\hline $\begin{array}{l}\text { Internal doctoral } \\
\text { student (Taught } \\
\text { Doctorate) }\end{array}$ & $3 * *$ & $100 * *$ & 5400 & Dr. rer. pol. \\
\hline $\begin{array}{l}\text { External doctoral } \\
\text { student (Tradi- } \\
\text { tional Ph.D.) }\end{array}$ & $3-4^{*}$ & $10-50 *$ & $540-3600$ & Dr. rer. pol. \\
\hline \multicolumn{5}{|c|}{$\begin{array}{l}\text { The data is based on experiences (indicated with a } * \text { ), formal rules }(* *) \text { and contractual clauses } \\
(* * *) \text {. Parameters are: working contracts for internal doctoral students are } 40 \text { hours a week for a } \\
100 \% \text { contract. The workload concept is the common instrument to quantitatively plan study pro- } \\
\text { grams after Bologna. } 1800 \text { hours of student's workload have to be planned per year. Working } \\
\text { hours for an external student in her/his company are assumed with } 40 \text { hours per week, which is } \\
\text { usually too little. Study hours on weekends, holydays or in vacation time are not included. }\end{array}$} \\
\hline
\end{tabular}

Given how the high level of acceptance of the doctoral degree by industry has positively impacted research at Osnabrueck and other German universities, it is somewhat surprising that - in the U.S. - the business professional doctorate is virtually unknown at research-focused universities (the program at Case Western's Weatherhead School being the single exception that we could identify). The principal obstacle, we suggest, is that U.S. universities view their doctoral programs in terms of potential for knowledge creation, as opposed to informing. We now explore the arguments for this perspective in detail.

\section{The Missing U.S. Professional Doctorate}

Why is the professional business doctorate virtually nonexistent at U.S. research universities? Prior to considering the question in depth, it is important to identify a number of objections that 
are NOT supported by international experiences and those of non-research institutions. Among these:

- There is no student demand for such programs. This is clearly not supported by the facts. Internationally, such programs have been growing rapidly and in the U.S. nonAACSB accredited programs such as that offered by Robert Morris University (RMU) have proved robust in their ability to maintain enrollments.

- Student attrition rates will be prohibitive. This is contrary to the experiences of existing programs. RMU, for example, succeeded in achieving $90 \%$ completion rates for its three year programs (Kohun \& Ali, 2005). In the U.K., addressing low completion rates for research Ph.D.s was one of the motivations identified for introducing professional programs (Huisman \& Naidoo, 2006).

- Industry has no interest in such programs. Internationally-especially in Germanyindustry demand for terminally qualified graduates is clearly evident. Because such programs are rare in the U.S., demand is hard to assess. In similar fields - most notably education, economics and government - a doctorate does confer some benefits, however.

- Such programs would be too costly. Actual evidence suggests that such programs can generate revenue well in excess of costs (e.g., Caldwell et al., 2007; Neumann, 2005), making such programs more comparable to the Executive MBA programs so prized by premier research universities.

- Such programs would jeopardize accreditation. To the contrary, the AACSB has recommended the establishment and expansion of such programs as a means of addressing a predicted shortage of business faculty (AACSB, 2002, p. 30; 2003, p. 18) and includes doctoral programs placing students in industry within its framework for research impact (AACSB, 2008, p. 31).

Ironically, the U.S. has traditionally been a world leader in research and doctoral innovation (as well introducing the first professional doctorate outside of medicine, the EdD introduced by Harvard University in 1921; Bourner et al. 2001). In order to understand why the U.S. has failed to embrace professional business doctoral programs, we need to examine the relative priority placed upon knowledge creation versus informing at U.S. institutions.

\section{Knowledge Creation vs. Informing In U.S. Business Research}

If we conceive of an academic discipline as an informing system, we can divide informing activities into two categories: informing internal clients (i.e., other researchers) and informing external clients. Our external clients - e.g., students, businesses, the local community, funding agenciesare, to a great extent, shared with the institutional informing system (i.e., the university), which provides resources to each discipline (e.g., salaries, facilities, travel funds) that are, to a great extent, dependent upon the discipline's service to the institutional clients (Gill \& Bhattacherjee, 2007). This is illustrated in Figure 1.

In the MIS disciplinary informing system, U.S. researchers have been found to favor informing internal clients (i.e., pure research and knowledge creation) to the exclusion of nearly all external clients (Gill \& Bhattacherjee, 2007). This preference for internal client informing, however, generalizes to nearly all business research disciplines in the U.S. (Gill \& Bhattacherjee, 2009; Pfeffer, 2007). The situation has become so serious that the AACSB has made improving the impact on practice of business research a central priority (e.g., AACSB, 2008). 


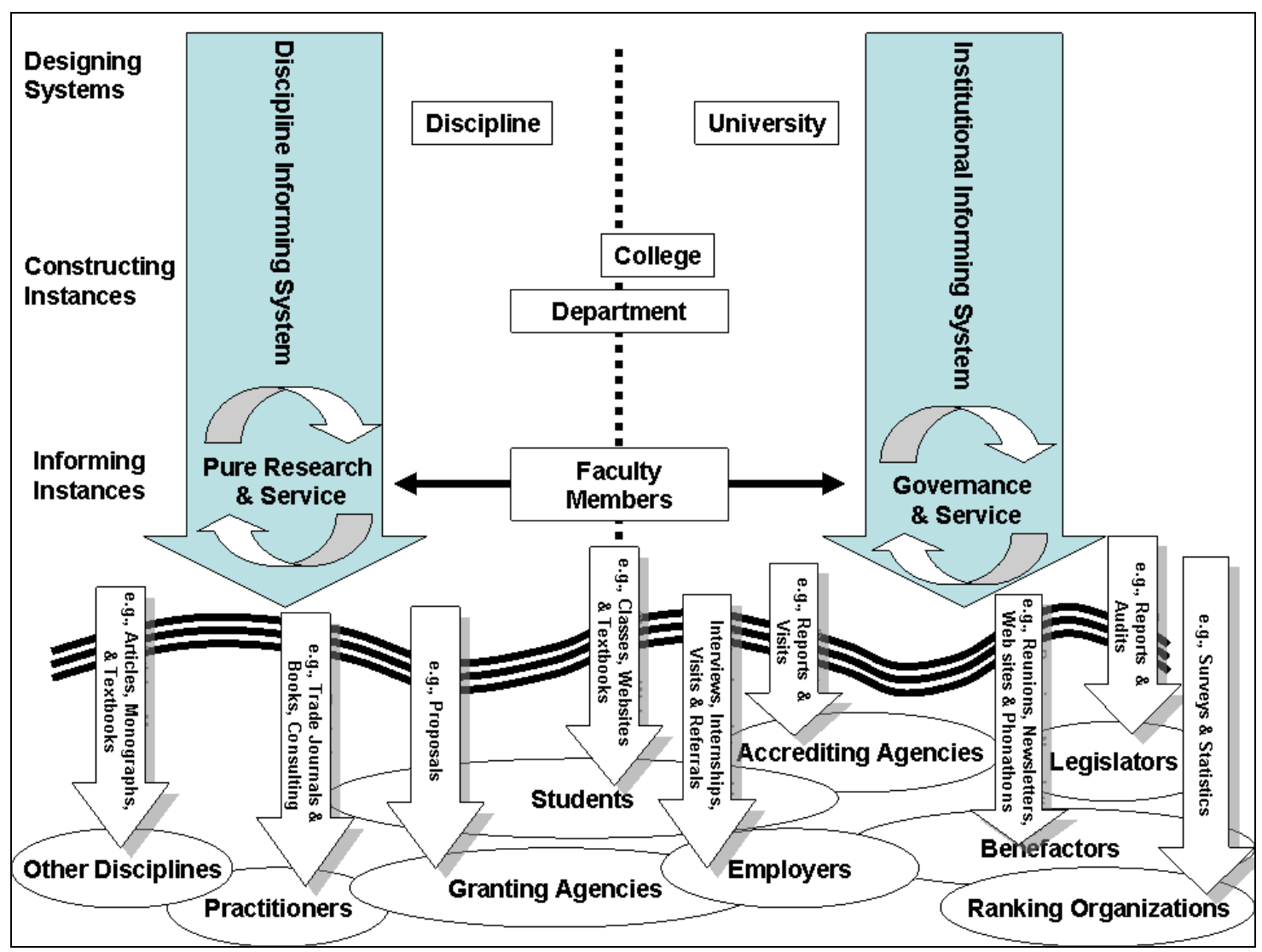

Figure 1: Disciplinary and institutional informing systems (from Gill \& Bhattacherjee, 2007). Disciplinary internal client informing activities are illustrated by the circular pattern labeled "pure research and service."

As should be evident from the earlier Table 3 (differences between academic and professional doctorates) and Table 6 (research findings from the U.K. and commonwealth countries), when pure research and journal publications are a discipline's principal priority, initiating a professional doctorate will be vastly less attractive than initiating an equivalent academically-focused program. Among the drawbacks of the professional program are included:

- Lack of tie-in between problems being investigated and gaps in the research literature,

- Project rather than publication emphasis, requiring the narrow disciplinary focus of an academic dissertation be broadened to encompass real world realities,

- Likelihood of part time or otherwise employed students who cannot help assume teaching duties or assist in faculty member research projects and grant-writing,

- Reduced ability to enforce direction on students who are paying their own way and who are likely to be senior professionals in their own right,

- Unwillingness of students who intend to remain in industry to socialize to the academic culture.

Perhaps even more important - although less likely to be openly admitted - is the perception that reduced prestige accompanies such programs. For example, the AACSB appears to be encouraging the development of such programs. Nonetheless, in their "strategic" models (AACSB, 2008, p. 31) they place professional doctoral programs in a lower category than disciplinary research doctoral programs. Since that same category — which also includes practice-focused research-is 
associated with institutions that pay less, are less likely to hire research faculty members, and are not generally well known at the national level, the U.S. professional doctorate appears to have been damned with faint praise.

The problem with focusing entirely on pure research is that it is probably not sustainable in the long term. The notion that the researcher's role ends with knowledge creation and that subsequent informing processes are beyond the scope of the researcher's responsibility fails to recognize that access to institutional resources, over the long run, depends almost entirely on service to external clients. The MIS discipline is probably the most egregious example of such focus. In the 1990s, it was sustained by huge enrollment growth that rendered it nearly invulnerable to denial of resources. Later, as a result of subsequent enrollment drops, it has started to experience a sharp decline in resources and is becoming extinct at top research institutions (Gill \& Bhattacherjee, 2009). Other business disciplines are likely to follow soon after. In short, if those of us who are business researchers do not find ways to inform and impact our external clients in a positive way, there is a very strong likelihood that such research will revert back to the low-status position that it held in academia prior to the 1970s.

We now turn to the question of the role that the business professional doctorate could play in establishing channels through which such informing can take place.

\section{Business Professional Doctorates as Sustainable Informing Channels}

The view that a professional doctorate could be valuable in putting research into practice is widely held (e.g., Caldwell et al., 2007; Coghlan, 2007; Lockhart \& Stablein, 2002). The general thrust of these arguments relates to the project-focus commonly associated with such programs. While we wholeheartedly endorse with this view-which is well demonstrated by the Osnabrueck examples - we also propose that the informing process should, indeed must, extend further and over a longer duration than the course of a student's enrollment. We draw upon the findings of complex informing processes (e.g., Gill \& Cohen, 2008) to support two propositions:

- The nature of business processes, combined with the differences between expert academic and expert practitioner knowledge structures, virtually guarantees that achieving academic-practitioner informing will be very hard.

- That the presence of professional doctorates in industry and, to a lesser extent, in academia, could significantly enhance opportunities for impactful informing.

The basic argument, more fully developed in the referenced papers, is now presented.

\section{Challenges of Academic Knowledge Transfer to Practice}

A recent monograph argued that the conveying of complex knowledge should be a central theme of informing science (Gill \& Cohen, 2008). In the proposed model, business knowledge transfer-in particular - is likely to face three major obstacles: 1) multiple solutions to business problems are likely to exist, leading to a rugged fitness landscape, 2) academic experts and practitioner experts are likely to hold very different models of the same business processes, and 3) many of the psychological filters that interfere with informing are likely to be very active in typical situations where academics are attempting to inform practitioners.

\section{Rugged fitness landscapes}

Business situations are very likely to be objectively complex, meaning that they consist of many attributes that are interrelated and are likely to be subject to dynamic changes in goals (Gill \& 
Hicks, 2006). For such situations, a single theory is unlikely to represent a useful solution to all problems. Instead, the fitness landscape - that is to say, the mapping between alternatives and the quality of solutions - is likely to exhibit many local peaks and valleys. Where a local peak is achieved, changes to any single aspect of the proposed solution leads to a decline in fitness. When viewed in the global context, however, the fitness of individual peaks can be well below the global maximum value. Where this is true, we have a rugged fitness landscape (Gill, 2008a).

Rugged fitness landscapes present a barrier to informing because practitioners tend to acquire expertise in a few peaks directly related to their experience. As such, their knowledge tends to be very effective with respect to performing on those peaks, but not always generalizable. In addition, their mental models tend to pick up unnecessary details. Academic interests, on the other hand, tend to be best served by ignoring specific peaks and focusing on those attributes that generalize well across the entire fitness landscape; the best theory is one that is both compact and generalizable. For this reason, their knowledge often omits critical details relating to specific situations and much of what they research and conclude falls under the heading of the obvious, or "low hanging fruit" (Gill, 2008a).

The fact that academic and practitioner models differ radically does not mean that they cannot benefit from information exchange. In a Cook County hospital, for example, extensive research into chest pain triage led to an algorithm for detecting heart attacks that was both much simpler than the personal heuristics developed by individual physicians and much more effective (Gladwell, 2005). In this case, researcher analysis proved more efficacious than practitioner expertise. In other cases, however, lessons from practice inform theory. For example, the field of expert systems emerged largely because, for many problems, mimicking the expertise of an individual practitioner proved more effective than attempting to perform a task using mathematical optimization or other theoretical means. Whatever the benefits, however, the fundamentally different perceptions of the landscape of interest will present a formidable barrier to informing.

\section{Alternative knowledge representations}

Just as practitioners and academics tend to have different views of the task domain they are considering, the structural form of that knowledge will tend to be very different as well. Acquiring expertise through research and study tends to lead to symbolic knowledge structures known to the ancient Greeks as episteme (Kessels \& Korthagen, 1996). The type of fluid expertise that comes with repetition of a task, and is often so deeply held that it cannot be articulated, is referred to as phronesis. In academic models, episteme tends to dominate. Practitioners, on the other hand, tend to accumulate phronesis through repeatedly performing their task. As a consequence, academics tend to inform using conceptual frameworks, employing abstract terms that are often unfamiliar to practitioners. By the same token, practitioners tend to employ a condensed jargon in their communications, very effective with other practitioners but confusing and too specific to meet the needs of academics (Gill, 2008d). Thus, differences in knowledge structures present a further barrier. The case is particularly acute for business researchers since other fields with professional doctorates (e.g., medicine) require that even academic researchers master the elements of professional practice through extensive clinical training.

\section{Cognitive filters}

A third barrier to practitioner-expert communications is a consequence of the cognitive filters that can cause communications to be ignored, attenuated, or distorted (Gill, 2008c; Jamieson \& Hyland, 2006). Many of these filters are impacted by biases - such as representativeness, availability, confirmation, and reasoning by analogy - that are likely to be particularly active in situations where two individuals have significantly different models of the same domain. 
Collectively, landscape ruggedness, alternative knowledge representations, and cognitive filters present formidable obstacles to effective informing from business academia to practice. Indeed, we would expect preferred academic informing channels - employing refereed journals and academic conferences - to be completely ineffectual. The degree of weakness actually observed in academic informing of practice in the U.S. strongly supports this expectation.

\section{Potential Role of Professional Doctorates}

The challenge of diffusing complex knowledge from research to practice is, quite obviously, not unique to business research. To the contrary, a large body of diffusion research addresses the subject of transferring ideas and technologies. We now consider some of the highlights of that research, and the role that professional doctorates might play.

\section{Diffusion processes}

Over the past seventy years, the subject of diffusion of complex ideas and technologies has been studied extensively, summarized in a seminal work by Rogers (2003). Gill (2008b, pp. 327-328) summarizes some of the key findings of this research as follows:

- Diffusion does not occur immediately but, instead, through a gradual process of adoption within the client community. Two forces that are particularly important for this process are mass media (i.e., any communication where a single sender provides information to multiple clients concurrently) and interpersonal communications within the client network. In general, mass media communications are more important in the earlier stages of communications, while interpersonal communications dominate later stages (Mahajan, Muller, \& Bass, 1991; Rogers, 2003).

- Diffusion processes often have to reach a "critical mass" after which diffusion starts to take off at a very rapid rate (Rogers, 2003, p. 349).

- Individuals within client communities are not homogeneous. Rather, they exhibit different characteristics with respect to their willingness to adopt innovations. These may be modeled in terms of thresholds (Rogers, 2003, p. 355). Idealized categories of adopters are often classified as: innovators, early adopters, early majority, late majority, and laggards (Rogers, 2003). Individuals may also exhibit different degrees of influence on other clients in the community (e.g., opinion leaders; Rogers, 2003, p. 300), awareness of the social nature of the community (e.g., key informants; Rogers, 2003, p. 310), and willingness to venture outside of their community and cumulative past experience (innovators; Rogers, 2003, p. 282).

A similar role for key players is proposed by Gladwell (2000), who identifies three distinct roles: 1) mavens: who thirst for knowledge and share it freely, 2) communicators: who maintain extensive networks of personal contacts and 3) persuaders: who are particularly adept at convincing individuals to adopt new ideas. These individuals, who are relatively rare, play a disproportionate role in nearly all complex diffusion processes.

\section{Roles for professional doctorates}

Based on experience in a variety of diffusion settings, we may expect that as little as $5 \%$ of complex diffusion is likely to occur through mass media informing channels, such as journal articles or even trade publications. The remainder results from face-to-face informing within the client community (Gill, 2008b). If we view informing external clients as being an essential part of the research process, it then follows that identifying those individuals who can play particularly 
prominent roles in face-to-face diffusion activities within the client community would be highly beneficial. What we propose is that a professional doctoral program offers an unusually good opportunity to identify such individuals.

There are a number of arguments we can make to support such a position. First and foremost, the easiest type of individual to inform is the maven, since they exhibit an unusual craving for information. Well supported by the motivational findings reported earlier in Table 4, the professional doctorate is likely to serve as a "maven trap" (see Gladwell, 2000, p. 276). It offers the individual the opportunity to learn more about the field, do research - a characteristic activity of mavensand to interact with other mavens. Moreover, if those mavens remain in industry subsequent to acquiring their doctorate, they will be almost guaranteed to continue following the literature; that is what mavens do. Indeed, the greatest drawback of using doctoral programs as maven traps is that it may be hard to convince such student not to leave industry and transition to academia. Careful program design, discussed in the final section, may serve to minimize this phenomenon.

By positioning a program as an executive doctorate, focusing on the later stages of the mid-career manager, we may also succeed in recruiting persuaders, or at least individuals who are at a level within their organizations where they can exert formal influence with respect to the adoption of ideas or business practices. Where these individuals are not mavens, however, ongoing personal contacts with faculty members to keep them connected to academic research may be needed.

One particular type of individual, the communicator, may best serve the needs of informing by joining academia. Since these individuals tend to maintain their extraordinarily large personal networks as a matter of habit, they could be extraordinarily valuable in identifying and acquiring sites for research and for moving information out into the field.

\section{Designing Professional Doctorates for Informing}

What we have proposed is that professional doctorates be conceived of as a tool for constructing informing channels between academia and practice. Designed for this purpose, such programs are likely to look very different from the academic model. In this context, we consider doctoral student socialization, the role of professional doctorates in a network model and, finally, some design considerations for such programs.

\section{Socialization and Professional Doctoral Students}

In the traditional U.S. doctoral program, effective socialization of the incoming students has been identified as an important element of career success and avoiding attrition (e.g., Austin, 2002; Golde, 1998; Trocchia \& Berkowitz, 1999). The purpose of such socialization is to ensure the candidate develops behaviors, values, and norms appropriate to academic life. While business academics frequently tout their independence of thought, their career success depends - to a great extent - on accepting shared beliefs regarding the importance of their research and the suitability of refereed publications as a critical — if not the only - measure of professional accomplishment. That we can do so in business in light of the overwhelming evidence that our research and publications have negligible impact on practice (e.g., Gill \& Bhattacherjee, 2009; Pfeffer, 2007) is de facto evidence of our successful socialization.

On the other hand, if a professional doctorate is to be successfully employed as a mechanism for informing practice, intentionally socializing the students to academic norms must be avoided. Once socialized, there would be little reason for these students to remain in practice. Then, with the possible exception of Gladwell's (2000) communicators - who maintain linkages as a matter of course - the very connections that would make the students invaluable for informing practice would rapidly dissipate. Once this occurs, we are left with a practice-experienced faculty member (which is certainly not a bad thing!) but not an informing channel. 


\section{Network Model of Professional Doctorates}

In network theory, the concept we are describing is sometimes referred to as a "small world model" (Watts, 2003). The finding that connections between any two people in the world can be established with a relatively small number of social links (generally six or less) has been popularized in games such as the Six Degrees of Kevin Bacon, where linkages between actors and Bacon are established through participation in common films. The small number of steps involved is - to a great extent - counterintuitive and surprised early investigators because we tend to operate in social groups where most people know each other, such as college faculty members. What makes the linkages possible, then, is the occasional connection we have to other social networks, illustrated in Figure 2 by the links between clusters.

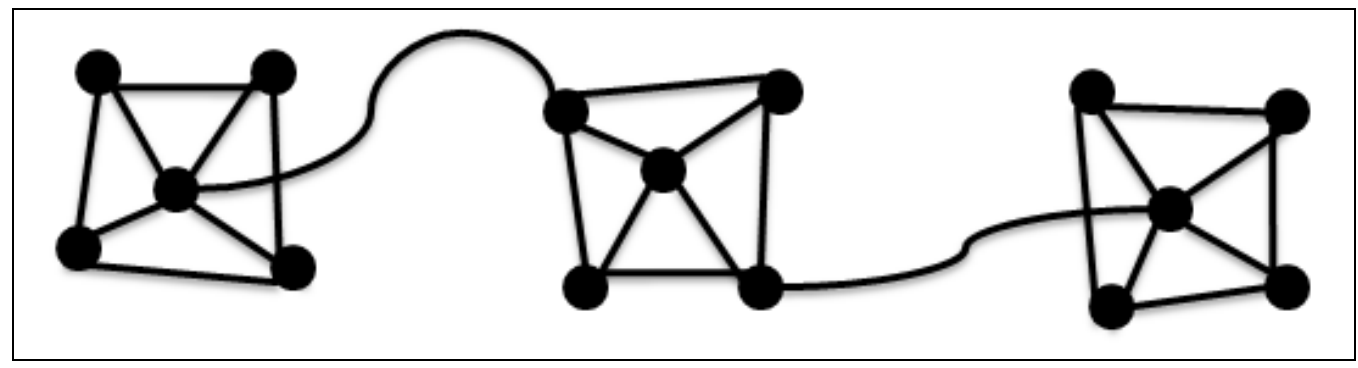

Figure 2: Small world model (Watts, 2003), showing tightly connected clusters tied together by a small number of cross cluster links. In our model, professional doctoral graduates (and students) would act as links between academic and practice communities.

Figure originally included in Gill (2008b).

To act as an effective informing channel, we therefore need our professional doctoral students to act as these external linkages to practice. Specifically, we would anticipate these individuals would link three distinct communities:

- The local business community of which they are a member

- The professional functional community (e.g., marketing, finance, MIS)

- The disciplinary research community at the institution where they received their training

Interestingly, this role suggests some unusual design guidelines for such programs

\section{Design Guidelines}

The characteristics envisioned for an informing-focused business professional doctorate are summarized in Table 7. It is probably no exaggeration to assert that such a program design would produce a tsunami of resistance from traditional research-oriented faculty members. Such a reaction is completely understandable when viewed from the perspective of knowledge creation and internal client informing, the current values that drive business academia. Indeed, it would probably be difficult to come up with a worse program design if one's objective is the production of refereed journal articles and placement of graduates at research extensive universities. But, of course, that is not the design intent of such a program. Research faculty members have, for the most part, come to terms with executive programs - in large part because they meet some of the informing and resource-generation objectives of the proposed doctoral program design. Executive MBAs and short programs are, however, a poor substitute for a professional doctorate because, for the most part, they are careful to shield students from academic research. That would most definitely not be the case for the proposed business professional doctorate. Candidates would need to understand the literature in order to become effective interpreters and communicators of its lessons to practice. 
Table 7: Recommended design characteristics for business professional doctoral programs

\begin{tabular}{|c|c|c|}
\hline Design & $\begin{array}{l}\text { Recommenda- } \\
\text { tion }\end{array}$ & Explanation \\
\hline $\begin{array}{l}\text { Institutions } \\
\text { most suited to } \\
\text { offer } \\
\text { programs }\end{array}$ & $\begin{array}{l}\text { Research } \\
\text { extensive or } \\
\text { intensive } \\
\text { universities }\end{array}$ & $\begin{array}{l}\text { - If the objective of these programs is to create a channel that } \\
\text { allows research to diffuse to practice, it should be situated in a } \\
\text { research university. } \\
\text { This represents a significant divergence from current practice, } \\
\text { particularly in the U.S. }\end{array}$ \\
\hline $\begin{array}{l}\text { Targeted } \\
\text { students }\end{array}$ & $\begin{array}{l}\text { Senior managers, } \\
\text { executives and } \\
\text { consultants }\end{array}$ & $\begin{array}{l}\text { - Senior managers and executives have the position to impact } \\
\text { practice } \\
\text { - Consultants offer access to an extraordinarily large group of } \\
\text { client companies } \\
\text { - All should be subject matter experts (SME) }\end{array}$ \\
\hline Organization & Cohort-based & $\begin{array}{l}\text { - Nearly all successful professional programs employ this } \\
\text { structure }\end{array}$ \\
\hline $\begin{array}{l}\text { Admission } \\
\text { Requirements }\end{array}$ & $\begin{array}{l}\text { Masters degree } \\
\text { and high } \\
\text { academic } \\
\text { performance }\end{array}$ & $\begin{array}{l}\text { - For program to succeed it must limit itself to top students } \\
\text { - Where exceptions are made, they should be for students whose } \\
\text { background demonstrates exceptional informing potential }\end{array}$ \\
\hline Instructors & $\begin{array}{l}\text { Research faculty } \\
\text { members with } \\
\text { use of visiting } \\
\text { faculty, as } \\
\text { necessary }\end{array}$ & $\begin{array}{l}\text { - Visiting faculty members could be used to broaden network of } \\
\text { student connections and tailor program to individual student } \\
\text { interests }\end{array}$ \\
\hline Curriculum & $\begin{array}{l}\text { Broad and } \\
\text { multidisciplinary, } \\
\text { includes } \\
\text { informing as } \\
\text { topic }\end{array}$ & $\begin{array}{l}\text { - SME students should require minimal exposure to disciplinary } \\
\text { concepts } \\
\text { - Sufficient research methods muse be covered to permit students } \\
\text { to be informed consumers of academic literature } \\
\text { - It would be unethical to groom students for informing purposes } \\
\text { without explaining the purpose for which they were admitted }\end{array}$ \\
\hline Thesis & $\begin{array}{l}\text { Project-oriented } \\
\text { action research }\end{array}$ & $\begin{array}{l}\text { - Goal of program is developing informing channels, not } \\
\text { disciplinary knowledge creators } \\
\text { - Action research makes time demands of program less onerous }\end{array}$ \\
\hline Attendance & $\begin{array}{l}\text { Part time, with } \\
\text { limited residency }\end{array}$ & $\begin{array}{l}\text { - Students must maintain employment in order to remain effective } \\
\text { informing channels } \\
\text { - Senior managers and executives are unlikely to want to leave } \\
\text { their job unless planning to retire or transition to academia- } \\
\text { both of which defeat the informing objective }\end{array}$ \\
\hline Delivery & $\begin{array}{l}\text { Heavy use of } \\
\text { distance learning }\end{array}$ & 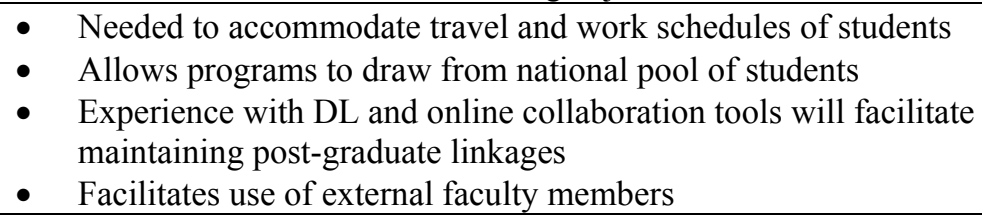 \\
\hline $\begin{array}{l}\text { Alumni } \\
\text { Outreach }\end{array}$ & Intensive & $\begin{array}{l}\text { - Maintaining enduring connections with graduates is critical to } \\
\text { success of program's informing mission } \\
\text { - Alumni could supply excellent research sites }\end{array}$ \\
\hline Fees & High & $\begin{array}{l}\text { - The target group of students has ability to pay } \\
\text { - For such programs to be accepted by non-participating research } \\
\text { faculty members, they must throw off considerable resources }\end{array}$ \\
\hline
\end{tabular}




\section{Conclusions}

The purpose of this paper has been to propose that professional doctorates in business be conceptualized as informing channels between academia and practice and be redesigned accordingly. Key conclusions are as follows:

1. Professional business doctorates are proliferating rapidly in the English-speaking world outside of the U.S. but have yet to establish an important role in the U.S. In Europe, particularly Germany, many students enroll in traditional doctorates with the express intent of transitioning to industry, where the degree is valued.

2. Business professional doctorates are practical from both the standpoint of student demand and financial performance. They would also be welcomed by accrediting agencies.

3. Resistance to business professional doctorates in the U.S. stems mainly from an academic preoccupation with knowledge creation (e.g., theory development) and internal client informing (e.g., refereed publications), neither of which are likely to be well-served by professionally-focused doctoral programs.

4. Our failure to consider external client informing as an integral part of the research process represents a major threat to the sustainability and prestige of business research programs.

5. Business professional doctoral programs can be viewed as a tool for developing informing channels between academia and practice. The type of students attracted to such programs would be particularly well-suited to that role.

6. If business professional doctorates are to be used to create informing channels, they need to be designed for that purpose. That includes adopting many practices that would be viewed as entirely unacceptable in most research-oriented doctorates, including: a parttime design where outside employment is required, heavy use of distance learning to provide flexibility and long term-connectivity with faculty members, a multidisciplinary curriculum that places little emphasis on teaching disciplinary skills, and a lock-step cohortbased organization.

Although the central theme of the paper has been enhancing the channel through which knowledge can flow from academia to business practice, we cannot conclude without noting that the same channel is likely to support an informing flow in the opposite direction-from practice to academia - that could easily be of equal or greater importance. Like some professional fields (e.g., education) and unlike others (e.g., medicine, law), the "client" of the academic-business informing channel is the source of nearly all observable data and is also the source of most of our knowledge of effective practice (see Pfeffer, 2007, for a discussion of where knowledge originates in the management field). Thus, the benefits of enhancing such channels through offering professional doctorates are likely to be at least as great on the academic side as they are to practice.

Finally, it should be readily apparent that the professional doctorate is not the only mechanism though which academic-practitioner channels can be developed or enhanced. Other activities that require close collaboration, such as consulting activities, case writing, executive-in-residence programs, and sabbaticals in practice, could also be employed to achieve better diffusion of academic knowledge. We believe, however, that the development of such professional doctoral programs, particularly at top research institutions, could - over the course of many years - serve as a major engine for transforming business research in the U.S. and elsewhere. The first step to motivating such programs, however, is recognizing that effective informing of practice is integral to any sustainable program of business research. 


\section{References}

AACSB (2002). Management education at risk, Tampa, FL: AACSB International. Retrieved from http://www.aacsb.edu/publications/metf/metfreportfinal-august02.pdf

AACSB (2003). Sustaining scholarship at business schools, Tampa, FL: AACSB International. Retrieved from http://www.aacsb.edu/resource_centers/doctoraledu/SustainingScholarship.pdf

AACSB (2008). Final report of the AACSB International impact of research task force, Tampa, FL: AACSB International. Retrieved from http://www.aacsb.edu/resource centers/research/Final/Impact of Research_Report-FINAL.PDF

Austin, A. E. (2002). Preparing the next generation of faculty: Graduate school as socialization to the academic career. The Journal of Higher Education, 73(1), 94-122.

Baldauf, B. (1998). Doctoral education and research training: Towards a more structured and efficient approach? European Journal of Education, 33, 161-182.

Bareham, J., Bourner, T., \& Stevens, G. R. (2000). The DBA: What is it for? Career Development International,5, 394.

Boud, D., \& Tennant, M. (2006). Putting doctoral education to work: Challenges to academic practice. Higher Education Research \& Development, 25(3), 293-306.

Bourner, T., Bowden, R., \& Laing, S. (2001). Professional doctorates in England. Studies in Higher Education, 26(1), 65-83.

Caldwell, C., White, H., \& Owl, R. H. R. (2007). The case for creating a DBA program - a virtue-based opportunity for universities. Journal of Academic Ethics, 5, 179-188.

Coghlan, D. (2007). Insider action research doctorates: Generating actionable knowledge. Higher Education, 54, 293-306.

Crosier, D., Purser, L., \& Smidt, H. (2007). Trend V: Universities shaping the European higher education area. EUA report. Retrieved from http://www.eua.be/fileadmin/user_upload/files/Publications/EUA_Trends_V_for_web.pdf

duz SPEZIAL (2004). Die Situation der Doktoranden in Deutschland. Ergebnisse der Befragung, 13-22.

EmploymentDigest.Net (2006). How much is an online degree worth? Retrieved from http://www.employmentdigest.net/2006/03/how-much-is-an-online-degree-worth/

Enders, J., \& Bornmann, L. (2001). Karriere mit Doktortitel? Ausbildung, Berufsverlauf und Berufserfolg von Promovierten, Frankfurt/Main: Campus.

Fink, D. (2006). The professional doctorate: its relativity to the Ph.D. and relevance for the knowledge economy. International Journal of Doctoral Studies, 1, 35-44. Retrieved from http://ijds.org/Volume1/IJDSv1p035-044Fink14.pdf

Franck, E., \& Opitz, C., (2007). The singularity of the German doctorate as a signal for managerial talent: causes, consequences and future developments. Management Revue, 18(2), 220-241.

Georgia State University (2008). Robinson names leadership team for new executive doctorate program. Retrieved, August 28, 2008, from http://robinson.gsu.edu/news/08/execdoctorate.html

Gladwell, M. (2000). The tipping point. New York: Back Bay Books.

Gladwell, M. (2005). Blink. New York, NY: Back Bay Books.

Gill, T. G. (2008a). Reflections on researching the rugged fitness landscape. Informing Science: the International Journal of an Emerging Transdiscipline, 11, 165-196. Retrieved from http://inform.nu/Articles/Vol11/ISJv11p165-196Gill219.pdf

Gill, T. G. (2008b). Resonance within the client-to-client system: Criticality, cascades, and tipping points. Informing Science: the International Journal of an Emerging Transdiscipline, 11, 311-348. Retrieved from http://inform.nu/Articles/Vol11/ISJv11p311-348Gill221.pdf 
Gill, T. G. (2008c). The single client resonance model: Beyond rigor and relevance. Informing Science: the International Journal of an Emerging Transdiscipline, 11, 281-310. Retrieved from http://inform.nu/Articles/Vol11/ISJv11p281-310Gill222.pdf

Gill, T. G. (2008d). Structural complexity and effective informing. Informing Science: the International Journal of an Emerging Transdiscipline, 11, 253-279. Retrieved from http://inform.nu/Articles/Vol11/ISJv11p253-279Gill223.pdf

Gill, T. G., \& Bhattacherjee, A. (2007). The informing sciences at a crossroads: The role of the client, Informing Science: the International Journal of an Emerging Transdiscipline, 10, 17-39. Retrieved from http://inform.nu/Articles/Vol10/ISJv10p017-039Gill317.pdf

Gill, T. G., \& Bhattacherjee, A. (2009). Whom are we informing? Issues and recommendations for MIS research from an informing sciences perspective, MIS Quarterly, 33(2), 217-235.

Gill, T.G., \& Cohen, E. (2008). Themes in complex Informing. Informing Science: the International Journal of an Emerging Transdiscipline, 11, 147-164. Retrieved from http://inform.nu/Articles/Vol11/ISJv11p147-164GillIntro.pdf

Gill, T. G., \& Hicks, R. (2006). Task complexity and informing science: A synthesis. Informing Science: the International Journal of an Emerging Transdiscipline, 9, 1-30. Retrieved from http://inform.nu/Articles/Vol9/v9p001-030Gill46.pdf

Golde, C. (1998), Beginning graduate school: Explaining first-year doctoral attrition. New Directions For Higher Education, 101, 55-64.

Hoffer, T. B., Hess, M., Welch, Jr., V., \& Williams, K. (2007), Doctorate recipients from united states universities: Summary report 2006, Chicago, Illinois: NORC at the University of Chicago.

Huisman, J., \& Naidoo, R. (2006). The professional doctorate: from Anglo-Saxon to European challenges. Higher Education Management and Policy, 18(2), 1-13.

Jamieson, K., \& Hyland, P. (2006). Good intuition or fear and uncertainty: The effects of bias on information systems selection decisions. Informing Science: the International Journal of an Emerging Transdiscipline, 9, 49-69. Retrieved from http://inform.nu/Articles/Vol9/v9p049-069Jamieson60.pdf

Janson, K., Schomburg, H., \& Teichler, U. (2006). Wissenschaftliche Wege zur Professur oder ins Abseits? Strukturinformationen zu Arbeitsmarkt und Beschäftigung an Hochschulen in Deutschland und den USA, Kassel.

Kennesaw State University (2008). The Coles School of Business. Retrieved November 16, 2008, from http://coles.kennesaw.edu/KSUColes/CurrentStudents/

Kessels, J. P. A., \& Korthagen, F. A. J. (1996). The relationship between theory and practice: Back to classics. Educational Researcher, 25(3), 17-22.

Khurana, R. and Nohria, N. (2008), It's time to make management a true profession, Harvard Business Review, October, 70-77.

Kohun, F., \& Ali, A. (2005). A doctorate degree program in information systems of a kind. Issues in Informing Science, 2, 179-188.

Leonard, D., Becker, R., \& Coate, K. (2005). To prove myself at the highest level: The benefits of doctoral study. Higher Education Research \& Development, 24(2), 135-149.

Lester, S. (2004). Conceptualizing the practitioner doctorate. Studies in Higher Education, 29(6), 757-770.

Lockhart, J. C., \& Stablein, R. E. (2002). Spanning the academy-practice divide with doctoral education in business. Higher Education Research \& Development, 21(2), 191-202.

Mahajan, V., Muller, E., \& Bass, F. M. (1991). New product diffusion models in marketing: A review and directions for research. In N. Nakicenovic \& A. Grubler (Eds), Diffusion of technologies and social behavior (pp. 125-177). New York, NY: Springer-Verlag. 
Maxwell, T. (2003). From first to second generation professional doctorate. Studies in Higher Education, 28(3), 279-291.

Mintzberg, H. (2004). Managers, not MBAs. San Francisco, CA: Berrett Koehler.

Neumann, R. (2005). Doctoral Differences: Professional doctorates and Ph.D.s compared. Journal of Higher Education Policy and Management, 27(2), 173-188.

Park, C. (2005). New Variant Ph.D.: The changing nature of the doctorate in the UK. Journal of Higher Education Policy and Management, 27(2), 189-207.

Pfeffer, J. (2007). A modest proposal: How we might change the process and product of managerial research. Academy of Management Journal, 50(6), 1334-1045.

Recotillet, I. (2007). Ph.D. Graduates with Post-doctoral Qualification in the Private Sector: Does It Pay Off? Labour, 21, 473-502.

Rogers, E. M. (2003). Diffusion of innovations (5th ed.). New York, NY: Free Press.

Statistisches Bundesamt (2008). Bildung und Kultur. Personal an Hochschulen, 2007, Fachserie 11, Reihe 4.4, Wiesbaden.

Trocchia, P. J., \& Berkowitz, D. (1999). Getting doctored: A proposed model of marketing doctoral student socialization. European Journal of Marketing, 33(7/8), 746-759.

Usher, R. (2002). A diversity Of doctorates: fitness for the knowledge economy? Higher Education Research \& Development, 21(2), 143-153.

Watts, D. J. (2003). Six degrees: The science of a connected age. New York, NY: Norton.

Wissenschaftsrat (2002). Empfehlungen zur Doktorandenausbildung, Retrieved from www.wissenschaftsrat.de/texte/5459-02.pdf

\section{Biographies}

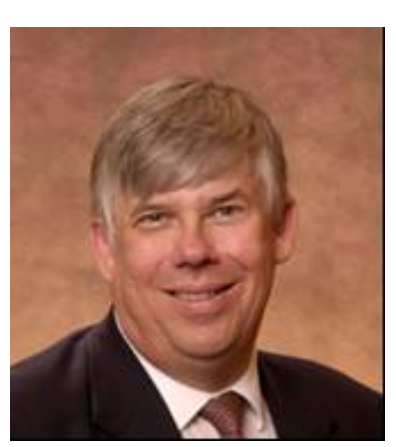

Grandon Gill is an Associate Professor in the Information Systems and Decision Sciences department at the University of South Florida. He holds a doctorate in Management Information Systems from Harvard Business School, where he also received his M.B.A. His principal research areas are the impacts of complexity on decisionmaking and IS education, and he has published many articles describing how technologies and innovative pedagogies can be combined to increase the effectiveness of teaching across a broad range of IS topics. Currently, he is Editor-inChief of Informing Science: The International Journal of an Emerging Transdiscipline and an Editor of the Journal of IT Education.

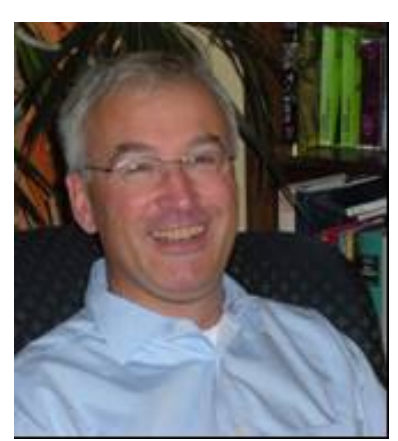

Uwe Hoppe is a tenured Professor in the Information Systems and Management department at the University of Osnabrueck, Germany. He holds a doctorate from University of Goettingen, where he also received his Diploma in Business Administration. His principal research areas are the impacts of Information Technologies on organizational structures and processes and the development and application of eLearning technologies like Campus Management Systems and Blended-Learning Environments. Currently, he is vice Head of Department at the college of Business Administration and Economics at University of Osnabrueck. 